\title{
Participatory Varietal Evaluation of Rainy Season Tomato under Plastic House Condition
}

\author{
Yama R. Pandey*, Amar B. Pun and Kalika P. Upadhyay \\ Regional Agricultural Research Station-NARC Lumle, PO Box 1, Kaski, Nepal
}

\begin{abstract}
Four tomato varieties namely LTH-61, Avinash-2, NSITH-162 and BL-410 were evaluated in farmer's field with farmers participation under plastic house condition for yield potential and other yield characters at Hemja, Kaski (920 masl) during rainy seasons of two consecutive years 2002 and 2003. The experiment was arranged in randomized complete block design with 5 replications, farmer as a replication. NSITH-162 took the shortest period of days to flowering and first harvest with an average of 36 and 66 days after transplanting respectively. Fruit set after flowering was highest in NSITH-162 (93.9\%) and the lowest in Avinash-2 (83.1\%). NSITH-162 produced the highest marketable fruit yield ( $89.05 \mathrm{t} / \mathrm{ha}$ ) and Avinash-2 produced the lowest $(51.98 \mathrm{t} / \mathrm{ha})$. The results of the experiment revealed that the hybrid varieties NSITH-162 and LTH-61 have more yield potentiality than open pollinated variety BL-410 and Avinash-2 an Indian hybrid variety and therefore NSITH-162 variety could be recommended for commercial production under plastic house condition.
\end{abstract}

Key words: Participatory, plastic house, rainy season, tomato

\section{INTRODUCTION}

Tomato (Lycopersicon esculentum) is one of the major commercial vegetable crops and widely grown both in the plains and hills of Nepal. In the hills, tomato can be produced successfully in two growing seasons, spring and rainy. Rainy season tomato is quite remunerative enterprise to the hill farmers as the supply from Tarai is constrained by high temperature, low fruit set, flowering, bacterial wilt etc. Tomato production during rainy season in open field condition is very difficult and the production during the season is very low. Tomato production inside plastic house during rainy season is a new and modest technology to farmers in the western hills of Nepal. The varieties recommended for spring season cultivation are Pusa Ruby, Roma, Monprecos and Money Maker (Bhattarai and Subedi 1996). Heat, blight and bacterial wilt susceptible varieties cannot be cultivated during rainy season. In addition to blight and wilt diseases, reduced fruit set due to high ambient temperature is also one of the important problems directly related to yield. Maximum day and minimum night temperature above $32^{\circ} \mathrm{C}$ and $21^{\circ} \mathrm{C}$ respectively are known to limit fruit set due to an impaired physiological process in flower and fruit setting and or abscission (Bhattarai and Subedi 1996). Though tomato is best suited to the Tarai, low and mid hills, it is becoming increasingly attractive for cash generation in the high hills also (Pandey and Chaudhary 2004). Problems of poor fruit set due to low temperature, high rainfall during flowering and blight disease in the mid to high hills and high temperature, rainfall, bacterial wilt, stem rot and viral diseases in the low hills are the most important factors limiting tomato cultivation on a commercial scale. However, tomato production inside the plastic house during rainy season has become very popular and profitable where there is market access. Since tomato is very expensive during rainy season, farmers could fetch good price besides its high initial investment cost. Jaiswal et al (1997) reported that BL-410 variety was found the most suitable in terms of good yield, attractive fruit shape and size and comparatively free from insect/pest and disease damage. 
There are two main approaches of producing rainy season tomato in the hills. The first option is the utilization of comparative advantage approach in which a particular area is identified for producing the product where during that time climate is favorable for the crop. Off-season vegetables could be produced with the introduction of heat and rain tolerant hybrids or open pollinated varieties especially for rainy season production (Pandey 2004). Though there are many reports on varietal selection, appropriate time of planting and pest and disease control measures for rainy season tomato, these constraints still prevail in the farmer's field. To develop rainy season tomato production as a remunerative enterprise, plastic house technology was found highly successful in the western hills where there is market access. Though the technology is highly successful, seed availability and varietal option has became major constraints in hills. Majority of tomato hybrid seed is imported from India and other countries and there is no certainty and varietal sustainability in the seed market. To provide alternative option of varieties and selection of suitable varieties, the experiment was conducted to evaluate different type of varieties in farmer's field under plastic house condition.

\section{MATERIALS AND METHODS}

The experiment was conducted at Outreach Research Site Hemja, Kaski (920 masl) of Regional Agricultural Research Station, Lumle during rainy seasons of two consecutive years 2002 and 2003. The experiment was arranged in a randomized complete block design (RCBD) with 5 replications, farmer as replication. Four popular, yet easily available varieties were included in the experiment. Among these varieties, LTH-61 and NSITH-162 were F1 hybrids developed in Nepal, Avinash-2 an Indian hybrid and BL-410 an open pollinated variety recommended by Regional Agricultural Research Station, Lumle in its research command area for rainy season production. The individual plot size was $12.6 \mathrm{~m}^{2}(2.1-\times 6-\mathrm{m})$ with one bed per plot, 6 rows in $90 \mathrm{~cm}$ apart in a bed and 7 plants per row, counting a total of 42 plants per plot. The size of plastic house was $5 \mathrm{~m}$ wide and $12 \mathrm{~m}$ long with $3 \mathrm{~m}$ height at the center. The experimental plot was equally divided into two plots longitudinally with $80 \mathrm{~cm}$ space at the center maintaining $2.1 \mathrm{~m}$ width of the experimental plot. All these varieties were seeded in the nursery on 30 May 2002 and 31 May 2003 and three weeks old seedlings were transplanted in the experimental plots on 21 June 2002 and 23 June 2003. Compost 40 tons and NPK 50:60:60 kg/ha was applied as basal dose during field preparation and additional dose of nitrogen $100 \mathrm{~kg} / \mathrm{ha}$ was applied as top dressing in two equal splits at 30 and 50 days after transplanting. In addition, pensibao $3^{\text {rd }}$ generation, a micronutrient was applied at 25, 45 and 75 days after transplanting. Irrigation was applied as and when necessary. The observations on days to flowering, days to first fruit harvest, number of clusters/plant, number of fruits/cluster, fruit set \%, marketable fruit yield, non-marketable fruit yield and plant stand (survivability) at harvest were collected and statistically analyzed using Genstat computer software.

\section{RESULTS AND DISCUSSION}

\section{Days to flowering from transplanting}

The major objective of this observation was to study the earliness character of the variety. The difference among the varieties on days to flowering from transplanting was highly significant (Table 1). NSITH-162 took the shortest period 35 days in 2002 and 36 days in 2003 whereas other two varieties LTH-61 and BL-410 took 39 days from transplanting to flowering. Avinash-2 took the longest period 40 days. However, there was only four days difference among the varieties on days to flowering from transplanting. Bhattarai and Subedi (1996) reported the flowering days of different varieties ranged from 53 to 74 days after transplanting in open field condition. Earlier flowering in this experiment might be due to the congenial growing environment in plastic house as compared to open field condition. 


\section{Days to first harvest from transplanting}

The major objective was to study the earliness character of the variety. The difference among the varieties on days to first harvest from transplanting was highly significant (Table 1). NSITH-162 took the shortest period 66 days from transplanting to first harvest whereas Avinash-2 and BL-410 took the longest period 71 days. However, there was only five days difference among the varieties on days to first harvest from transplanting. Earliness plays important role on fetching higher market price and more income. Even a single day is important for market price and total income from the product. Therefore early varieties are generally preferred for cultivation on commercial scale. The result of the varietal experiment conducted at Yampaphant (430 masl) in open field condition showed that days to first harvest from transplanting ranged from 93 to 115 days (Bhattarai and Subedi 1996). The earliness in this experiment might be due to the variety and congenial growing environment in plastic house as compared to open field condition.

Table 1. Performance of tomato varieties on flowering days, first harvest days and fruit set under plastic house condition at Hemja, Kaski during 2002 and 2003 rainy seasons

\begin{tabular}{|c|c|c|c|c|c|c|c|c|c|}
\hline \multirow[t]{2}{*}{ Variety } & \multicolumn{3}{|c|}{ Days to flowering from transplanting } & \multicolumn{3}{|c|}{ Days to first harvest from transplanting } & \multicolumn{3}{|c|}{ Fruit set, \% } \\
\hline & 2002 & 2003 & Mean & 2002 & 2003 & Mean & 2002 & 2003 & Mean \\
\hline Avinash-2 & 39 & 40 & 40 & 72 & 71 & 71 & 83.0 & 83.2 & 83.1 \\
\hline NSITH-162 & 35 & 36 & 36 & 67 & 66 & 66 & 93.0 & 94.8 & 93.9 \\
\hline LTH-61 & 39 & 39 & 39 & 70 & 70 & 70 & 90.0 & 91.6 & 90.8 \\
\hline BL-410 & 39 & 39 & 39 & 72 & 70 & 71 & 89.0 & 91.0 & 90.0 \\
\hline Mean & 38 & 39 & 38 & 70 & 69 & 70 & 88.8 & 90.2 & 89.5 \\
\hline$P$ value & $<.001$ & $<.001$ & $<.001$ & 0.001 & $<.001$ & $<.001$ & $<.001$ & $<.001$ & $<.001$ \\
\hline $\operatorname{LSD}(0.05)$ & 0.78 & 0.71 & 0.57 & 0.53 & 0.88 & 0.69 & 1.16 & 1.01 & 1.10 \\
\hline $\mathrm{CV}, \%$ & 1.5 & 1.3 & 1.6 & 0.6 & 0.9 & 1.1 & 0.9 & 0.8 & 1.4 \\
\hline
\end{tabular}

\section{Fruit set}

Fruit set percent on tomato varieties is one of the important parameters for summer and rainy season tomato production, which determines the resistance and tolerance of a variety to a particular temperature and environment. The fruit set percent was highly affected by the varieties (Table 1). The highest fruit set $(93.9 \%)$ was observed in NSITH-162 whereas, the lowest fruit set (83.1\%) was observed in Avinash2. It might be due to the adaptability of NSITH-162 in the local environment and tolerance to high temperature. The result revealed that higher the fruit set percentage more fruit yield is obtained. Fruit set percent is directly related to the fruit yield. In a varietal experiment Bhattarai and Subedi (1996) reported the fruit set percent ranging from 1 to 55\%. The difference in fruit set in different experiments might be due to the varietal character and growing environment.

\section{Plant stand or survivability at harvest}

Plant stand at harvest of the crop varieties is one of the important parameters for rainy and off-season production of vegetables, which determines the resistance and tolerance of a variety to a particular environment and incidence of pests and diseases. The survivability percent among the varieties was found significantly different (Table 2). The highest percentage of survivability at harvest (99.6\%) was observed in LTH-61 and BL-410 whereas the lowest percentage (77.2\%) was observed in Avinash-2. The survivability was $99.3 \%$ in NSITH-162. The low survivability in Avinash-2 was due to the incidence of bacterial wilt disease. Bacterial wilt disease is one of the major threats for rainy season tomato production. Plant stand at harvest or survivability depends on the varietal character, growing environment, disease and pest incidence, suitable to the existing environment etc.

\section{Number of clusters per plant}

The objective of this observation was to evaluate the varieties for fruiting character and the relation of clusters to the yield. The difference among the varieties on number of clusters/plant was highly significant (Table 2). The highest number of cluster (38.4) was produced by NSITH-162 whereas the lowest number of cluster (14.8) was produced by Avinash-2. Number of cluster per plant in LTH-61 was 28.5 and 19.6 in BL-410. It is one of the major criteria to select better variety for its higher yield 
and preferable fruit size. The number of clusters directly influenced the fruit yield. However, fruit size and fruit number per cluster are also determinant factors.

Table 2. Performances of tomato varieties on plant stand at harvest, fruit clusters/plant and fruits/cluster under plastic house condition at Hemja, Kaski during 2002 and 2003 rainy seasons

\begin{tabular}{lrrrrrrrrr}
\hline Variety & \multicolumn{3}{c}{ Plant stand at harvest, \% } & \multicolumn{3}{c}{ Number of cluster/plant } & \multicolumn{3}{r}{ Number of fruits/cluster } \\
\cline { 2 - 11 } & 2002 & 2003 & Mean & 2002 & 2003 & Mean & 2002 & 2003 & Mean \\
\hline Avinash-2 & 78.3 & 76.1 & 77.2 & 14.2 & 15.4 & 14.8 & 5.6 & 5.8 & 5.7 \\
NSITH-162 & 99.0 & 99.7 & 99.3 & 37.2 & 39.5 & 38.4 & 6.6 & 6.9 & 6.8 \\
LTH-61 & 99.5 & 99.6 & 99.6 & 27.4 & 29.6 & 28.5 & 5.4 & 5.7 & 5.6 \\
BL-410 & 99.5 & 99.7 & 99.6 & 18.8 & 20.4 & 19.6 & 5.2 & 5.8 & 5.5 \\
\hline Mean & 94.1 & 93.8 & 93.9 & 24.4 & 26.2 & 25.3 & 5.7 & 6.1 & 5.9 \\
P value & $<.001$ & $<.001$ & $<.001$ & $<.001$ & $<.001$ & $<.001$ & $<.001$ & $<.001$ & $<.001$ \\
LSD (0.05) & 6.22 & 0.61 & 2.79 & 0.43 & 0.73 & 1.03 & 0.28 & 0.20 & 0.25 \\
CV, \% & 4.8 & 0.5 & 3.3 & 1.3 & 2.0 & 4.5 & 3.6 & 2.5 & 4.7 \\
\hline
\end{tabular}

\section{Number of fruits per cluster}

The objective of this observation was to evaluate the varieties for fruiting character and effect of the fruit size and number to the yield. The difference among the varieties on number of fruits/cluster was significant (Table 2). The highest number of fruits (6.8) was produced by NSITH-162 whereas the lowest number of fruits (5.5) was produced by BL-410. However the fruits/cluster was at par in Avinash-2, LTH-61 and BL-410. It is one of the major criteria to select better variety for its higher yield and preferable fruit size. In general, higher the number of fruits/cluster more fruit yield is obtained but fruit size is also determining factor for yield estimation.

\section{Marketable fruit yield}

Marketable fruit yield is the major determinant variable for selecting a particular variety for its commercialization and income generation capability. The difference among the varieties on marketable fruit yield was highly significant (Table 3). NSITH-162 produced the highest marketable fruit yield (87.53 t/ha in 2002 and $90.56 \mathrm{t} / \mathrm{ha}$ in 2003 with combined yield $89.05 \mathrm{t} / \mathrm{ha}$. Similarly, LTH-61 produced $76.33 \mathrm{t} / \mathrm{ha}$ in 2002 and $77.47 \mathrm{t} / \mathrm{ha}$ in 2003 with combined yield $76.90 \mathrm{t} / \mathrm{ha}$. BL-410 open pollinated variety produced $70.13 \mathrm{t} / \mathrm{ha}$ in 2002 and $72.86 \mathrm{t} / \mathrm{ha}$ in 2003 with combined yield $71.50 \mathrm{t} / \mathrm{ha}$. The lowest yield $51.02 \mathrm{t} / \mathrm{ha}$ in 2002 and $52.93 \mathrm{t} / \mathrm{ha}$ in 2003 with combined yield $51.98 \mathrm{t} / \mathrm{ha}$ was produced by Avinash-2. In a varietal experiment conducted by Bhattarai and Subedi (1996) reported that the marketable fruit yield of open pollinated tomato varieties grown in open field condition ranged from 0.1 to $12 \mathrm{t} / \mathrm{ha}$. Many folds increase in fruit yield might be due to the variety and growing condition in plastic house.

Table 3. Performances of tomato varieties on marketable and non-marketable fruit yield under plastic house condition at Hemja, Kaski during 2002 and 2003 rainy seasons

\begin{tabular}{lrrrrrr}
\hline Variety & \multicolumn{3}{c}{ Marketable fruit yield, $\mathrm{t} / \mathrm{ha}$} & \multicolumn{3}{r}{ Non-marketable fruit yield, $\mathrm{t} / \mathrm{ha}$} \\
\cline { 2 - 7 } & 2002 & 2003 & Mean & 2002 & 2003 & Mean \\
\hline Avinash-2 & 51.02 & 52.93 & 51.98 & 2.49 & 2.41 & 2.45 \\
NSITH-162 & 87.53 & 90.56 & 89.05 & 6.50 & 5.21 & 5.86 \\
LTH-61 & 76.33 & 77.47 & 76.90 & 4.96 & 4.06 & 4.51 \\
BL-410 & 70.13 & 72.86 & 71.50 & 4.92 & 4.26 & 4.59 \\
\hline Mean & 71.25 & 73.46 & 72.35 & 4.72 & 3.99 & 4.35 \\
P value & $<.001$ & $<.001$ & $<.001$ & $<.001$ & $<.001$ & $<.001$ \\
LSD (0.05) & 0.94 & 1.13 & 1.35 & 0.24 & 0.23 & 0.46 \\
CV, \% & 1.0 & 1.1 & 2.1 & 3.7 & 4.2 & 11.7 \\
\hline
\end{tabular}

\section{Non-marketable fruit yield}

Non-marketable fruit yield is one of the major variables for selecting a particular variety for its economic yield potential and varietal character. The difference among the varieties on non-marketable 
fruit yield was highly significant (Table 3). NSITH-162 yielded the highest non-marketable fruit yield 5.86 t/ha. Similarly, BL-410 produced 4.59 t/ha and LTH-61 4.51 t/ha non-marketable fruit yield. The lowest yield (2.45 t/ha) was produced by Avinash-2. The results of the experiment revealed that the variety that produces higher marketable fruit yield also produces higher non-marketable fruit yield. In a varietal experiment conducted by Bhattarai and Subedi (1996) reported that the non-marketable fruit yield of open pollinated tomato varieties grown in open field condition ranged from 0 to $2.3 \mathrm{t} / \mathrm{ha}$.

The results of the experiment showed that NSITH-162 was the earliest variety for flowering, fruiting and harvesting. The highest fruit set observed in NSITH-162 indicates that this variety is more tolerant to heat and adverse environment. LTH-61, BL-410 and NSITH-162 have over 99\% plant survivability indicating that these varieties are suitable to the environment and resistant to bacterial wilt and other pests and diseases. NSITH-162 produced highest number of fruit clusters/plant, fruits/cluster and highest marketable fruit yield. The results of the experiment reveal that NSITH-162 could be recommended for rainy season production under plastic house condition.

\section{REFERENCES}

Bhattarai SP and PP Subedi. 1996. Heat and bacterial wilt tolerant tomato varietal evaluation during 1992/931994/95 season. LARC Working Paper No. 96/56. Lumle Agriculture Research Centre, Kaski, Nepal.

Jaiswal JP, SP Bhattarai and PP Subedi. 1997. Varietal and micronutrient trials on spring and rainy season tomato conducted at outreach research sites 1995/96. LARC Working Paper No. 97/22. Lumle Agriculture Research Centre, Kaski, Nepal.

Pandey YR and B Chaudhary. 2004. Evaluation of tomato varieties and their planting dates for commercial production under Jumla agro-ecological condition. In: Proceedings of the Fourth National Horticultural Research Workshop (BB Khatri, BP Sharma, PP Khatiwada, KP Paudyal BR Khadge and HN Regmi, eds). Horticulture Research Division-NARC, Khumaltar. Pp. 380-385.

Pandey YR. 2004. Evaluation of cauliflower varieties and planting dates for commercial production under Jumla agr-ecological condition. In: Agricultural research for enhancing livelihood of Nepalese people (BK Joshi, SL Joshi and KP Paudyal, eds). Proceedings of $2^{\text {nd }}$ SAS-N Convention, 30 July - 1 Aug 2003 Kathmandu. Pp. 207-210. 